\title{
Effects of rumen-protected choline and dry propylene glycol on feed intake and blood parameters for Holstein dairy cows in early lactation
}

\author{
Y.-H. Chung, N. E. Brown, C. M. Martinez, T. W. Cassidy, and G. A. Varga ${ }^{1}$ \\ Department of Dairy and Animal Science, The Pennsylvania State University, University Park 16802
}

\begin{abstract}
A $6 \times 6$ Latin square design was used to test 3 sets of comparisons simultaneously to study response in dry matter intake, milk yield, and blood parameters to propylene glycol (PG) supplementation delivered by 2 methods [incorporating $\mathrm{PG}$ into the total mixed ration (TMR) vs. top dressing; comparison I]; individual or combined dietary choline and PG supplementation as a $2 \times 2$ factorial (comparison II); or increasing amounts of dietary choline (comparison III). Six multiparous (lactation number $=1.5 \pm 0.8 \mathrm{SD}$ ) Holstein dairy cows were at $41 \mathrm{~d}$ in milk $( \pm 9 \mathrm{SD})$ at the start of the experiment. Propylene glycol used was a dry product containing $65 \% \mathrm{PG}$, and choline was a rumen-protected choline product (RPC; estimated to be $50 \%$ rumen-protected) containing $50 \%$ choline chloride. In comparison I, treatments compared were 1) control: no PG; 2) PG-TMR: $250 \mathrm{~g} / \mathrm{d}$ of dry PG (corresponding to $162.5 \mathrm{~g} / \mathrm{d}$ of $\mathrm{PG}$ ) incorporated into the TMR; and 3) PG-top dress: 250 $\mathrm{g} / \mathrm{d}$ of dry PG top-dressed onto the TMR. In comparison II, treatments compared were 1) control: no PG and no RPC; 2) PG: $250 \mathrm{~g} / \mathrm{d}$ of dry PG incorporated into the TMR; 3) RPC: $50 \mathrm{~g} / \mathrm{d}$ of RPC top-dressed onto the TMR; and 4) PG+RPC: combination of treatments 2 and 3 . In comparison III, treatments compared were 0,25 , and $50 \mathrm{~g} / \mathrm{d}$ of RPC top-dressed onto the TMR. Each experimental period lasted $10 \mathrm{~d}$ with $9 \mathrm{~d}$ of adaptation followed by $1 \mathrm{~d}$ of serial blood sampling. Dry matter intake and milk yield were recorded daily. During the serial blood sampling, jugular blood was sampled every $20 \mathrm{~min}$ for the first $4 \mathrm{~h}$ and at 8 and $12 \mathrm{~h}$ after treatment administration. Results obtained from comparison I showed that feeding $250 \mathrm{~g} / \mathrm{d}$ of PG as a dry product decreased plasma $\beta$-hydroxybutyrate (BHBA) concentration (mean \pm SEM) from $701 \pm 81$ (control) to $564 \pm 76 \mu \mathrm{mol} / \mathrm{L}$ without affecting serum insulin, plasma glucose, or plasma nonesterified fatty acid concentrations. Top-dressing PG decreased plasma BHBA concentrations more than by incorporating
\end{abstract}

Received April 24, 2008.

Accepted February 4, 2009.

${ }^{1}$ Corresponding author: gvarga@psu.edu it into the TMR $[527$ vs. $601 \mu \mathrm{mol} / \mathrm{L}( \pm 81$ pooled SEM)]. Results obtained from comparison II showed that supplementing choline as RPC, PG, or both had no effect on dry matter intake, milk yield, or any of the blood parameters measured. Results obtained from comparison III showed that milk yield tended to increase linearly with increasing amounts of dietary choline as RPC. We concluded that feeding PG as a dry product reduced plasma BHBA concentration but top-dressing PG was more efficient at reducing plasma BHBA level than incorporating PG into the TMR. Dietary choline as RPC tended to increase milk yield linearly. However, a combined effect of dietary PG and choline was not evident and therefore not beneficial.

Key words: rumen-protected choline, dry propylene glycol, feed intake, blood parameter

\section{INTRODUCTION}

Johnson (1954) demonstrated the ability of propylene glycol (PG) to effectively treat ketosis in dairy cows. Supplementation of PG by incorporating it into the concentrate has been shown to decrease blood concentrations of NEFA and BHBA (Fisher et al., 1971; Hoedemaker et al., 2004) and increase blood concentrations of glucose and insulin (Sauer et al., 1973; Patton et al., 2004). Feeding PG instead of routine oral drenching may be better accepted by dairy producers, as PG is a readily available energy supplement to alleviate negative energy balance and subsequently prevent subclinical ketosis. Lewis and Price (1957) demonstrated the ability of choline, via subcutaneous injection, to treat cows suffering from fatty infiltration in the liver after parturition. More recently, Cooke et al. (2007) demonstrated the ability of dietary choline to prevent and alleviate hepatic lipid accumulation in cows with experimentally induced fatty liver. The first hypothesis of the current study was that feeding PG as a dry product can improve energy status as indicated by key blood parameters. The first objective was to study responses of DMI, milk yield, and blood parameters to dry PG supplementation. Two delivery methods (top-dressing vs. incorporating into the TMR) for dry PG supplementation were studied to compare efficacy 
between delivery methods. The second hypothesis was that supplementing choline as rumen-protected choline can improve hepatic lipid metabolism thereby improving feed intake and milk production, and that the effects of choline and PG supplementations are additive. The second objective was to study the combined effects of choline and PG supplementation on DMI, milk yield, and blood parameters. The third hypothesis was that the effects of choline supplementation on improving feed intake and milk production were dose related. The third objective was to study responses of DMI, milk yield, and blood parameter to increasing amounts of choline as rumen-protected choline.

\section{MATERIALS AND METHODS}

\section{Experimental Design, Dietary Treatments, and Animal Care}

A $6 \times 6$ Latin square design was used to allow for 3 sets of comparisons (designated comparisons I, II, and III) to be made simultaneously. Six multiparous (lactation number $=1.5 \pm 0.8 \mathrm{SD}$ ) Holstein dairy cows were used and they were at $41 \mathrm{DIM} \pm 9 \mathrm{SD}$ at the start of the experiment. Cows weighed an average of 621.6 $\mathrm{kg} \pm 70.4 \mathrm{SD}$ (at $18 \mathrm{DIM} \pm 2 \mathrm{SD}$ ) with BCS of $2.9 \pm$ $0.2 \mathrm{SD}$ (at $21 \mathrm{DIM})$. In comparison I, cows were fed a basal lactation TMR (control) supplemented with 250 $\mathrm{g} / \mathrm{d}$ of $\mathrm{PG}$ as a dry product (corresponding to 162.5 $\mathrm{g} / \mathrm{d}$ of $\mathrm{PG}$ ) by incorporating the dry product into the TMR (PG-TMR) or as a top dress (PG-top dress) to study effects of feeding PG as a dry product and to compare between the 2 delivery methods for PG. The PG product used was a nonacidogenic dry product (Gly-Tran 65, NutriLinx LLC, Montpelier, VT; $\mathrm{NE}_{\mathrm{L}}=$ $2.6 \mathrm{Mcal} / \mathrm{kg}$ ), which was composed of $65 \% \mathrm{PG}$ and $35 \%$ silicon dioxide as the carrier. The amount of PG (162.5 $\mathrm{g} / \mathrm{d}$ ) chosen was similar to the amount of liquid $\mathrm{PG}$ (approximately $120 \mathrm{~g} / \mathrm{d}$ ) that is routinely drenched to fresh cows as a prevention treatment for subclinical ketosis. In comparison II, cows were fed a basal lactation TMR (control) supplemented with $250 \mathrm{~g} / \mathrm{d}$ of PG as a dry product incorporated in the TMR (PG; same as the PG-TMR treatment in comparison I), $50 \mathrm{~g} / \mathrm{d}$ of rumenprotected choline product top dressed onto the TMR (RPC), or both (PG+RPC) to study the individual or combined effects of PG and RPC. The RPC product (Pro-Choline 50, Probiotech Inc., Saint-Hyacinthe, Quebec, Canada) contained $50 \%$ choline chloride and was estimated to be $50 \%$ rumen-protected after in situ incubation in the rumen for $48 \mathrm{~h}$ based on the method described by Lykos and Varga (1995) (data not shown). The amount of postruminal choline (estimated to provide $12.5 \mathrm{~g} / \mathrm{d}$ ) was chosen based on the dose range (from 12 to $20 \mathrm{~g} / \mathrm{d}$ ) that has been shown to increase milk yield (Baldi and Pinotti, 2006). In comparison III, cows were fed a basal lactation TMR top dressed with 25 or $50 \mathrm{~g} / \mathrm{d}$ of RPC (estimated to provide 6.25 and $12.5 \mathrm{~g} / \mathrm{d}$ of postruminal choline, respectively) to study dose response effects of choline. For cows receiving $P G$ top-dressed, $500 \mathrm{~g} / \mathrm{d}$ of cookie meal (dried bakery byproduct) was mixed with the dry PG product to ensure consumption by cows, and most cows readily consumed it. A similar amount of cookie meal was top-dressed to all cows. Each experimental period lasted $10 \mathrm{~d}$ with $9 \mathrm{~d}$ of adaptation and serial blood sampling conducted on the last day. Dietary treatments were fed throughout each experimental period.

Cows were housed in a tunnel-ventilated tie-stall barn, milked twice daily at approximately 0630 and $1830 \mathrm{~h}$, and fed a basal lactating cow TMR (Table 1) once daily at approximately $0800 \mathrm{~h}$. The TMR was formulated based on NRC (2001) guidelines for Holstein dairy cows at $660 \mathrm{~kg}$ of BW and producing $41 \mathrm{~kg}$ of milk/d with $3.7 \%$ of milk fat. Feed refusals were weighed before feeding and the amount of feed offered was adjusted daily to allow $10 \%$ refusals. Feed was pushed up to cows approximately 4 to 6 times per day. Cows had access to an open dry lot for $2 \mathrm{~h}$ before each milking. Cows were handled and cared for under protocols approved by the Pennsylvania State University Institutional Animal Care and Use Committee.

\section{Measurements and Serial Blood Collection}

Samples of major forages (corn silage and alfalfa haylage) and TMR were collected weekly and stored at $-20^{\circ} \mathrm{C}$ for $\mathrm{DM}$ and chemical analysis. Individual asfed feed intake was recorded daily and milk production was recorded at each milking. However, only feed intake and milk production that were recorded from d 7 to 10 (excluding d 9 when cows were catheterized) of each experimental period were used for statistical analysis. Daily DMI was calculated by adjusting daily as-fed feed intake to DM percentage of the weekly TMR sample. During serial blood sampling, feed intake was recorded hourly for each cow for the first $4 \mathrm{~h}$ and again at 8 and $12 \mathrm{~h}$ after treatment administration.

On d 9 of each experimental period, a gas (ethylene oxide)-sterilized indwelling catheter (Tygon Micro-Bore Tubing, Saint-Gobain Performance Plastic Co., Aurora, $\mathrm{OH})$ was placed into the right jugular vein of each cow. On d 10, jugular blood was serially sampled via the jugular catheter immediately before treatment administration (designated as time 0) and at 20, 40, 60, 80, $100,120,140,160,180,200,220,240,480$, and $720 \mathrm{~min}$ after treatment administration. Catheters and extension tubings (Cook Inc., Bloomington, IN) were filled with 
Table 1. Ingredient and chemical composition of the basal lactation TMR

\begin{tabular}{|c|c|}
\hline Item & Means $\pm \mathrm{SD}$ \\
\hline $\begin{array}{l}\text { Ingredient, } \% \text { of the dietary DM } \\
\text { Corn silage }^{1} \\
\text { Alfalfa haylage }^{2} \\
\text { Cottonseed hulls } \\
\text { Alfalfa hay } \\
\text { Corn, dry shell } \\
\text { Soybeans, roasted } \\
\text { Cookie meal } \\
\text { Canola meal } \\
\text { Soybeans, }{ }^{3} \text { heat treated } \\
\text { Molasses, liquid } \\
\text { Mineral and vitamin premix } \\
\text { Sodium bicarbonate } \\
\text { Sodium bentonite }\end{array}$ & $\begin{aligned} 43.50 & \pm 1.52 \\
18.99 & \pm 2.26 \\
3.37 & \pm 0.22 \\
2.03 & \pm 0.06 \\
9.04 & \pm 0.64 \\
5.41 & \pm 0.48 \\
4.71 & \pm 0.32 \\
5.63 & \pm 0.55 \\
1.26 & \pm 0.06 \\
3.56 & \pm 0.11 \\
2.07 & \pm 0.06 \\
0.34 & \pm 0.01 \\
0.10 & \pm 0.005\end{aligned}$ \\
\hline $\begin{array}{l}\text { Chemical composition } \\
\text { DM, \% } \\
\text { CP, \% of DM } \\
\text { Soluble protein, \% of CP } \\
\text { ADF, \% of DM } \\
\text { NDF, \% of DM } \\
\text { NFC, \% of DM } \\
\text { Fat, \% of DM } \\
\mathrm{NE}_{\mathrm{L}}, \mathrm{Mcal} / \mathrm{kg} \\
\mathrm{Ca} \% \text { of DM } \\
\mathrm{P}, \% \text { of DM } \\
\mathrm{Mg}, \% \text { of DM } \\
\mathrm{K}, \% \text { of DM } \\
\mathrm{Na}, \% \text { of DM } \\
\mathrm{S}, \% \text { of DM } \\
\mathrm{Fe}, \mathrm{mg} / \mathrm{kg} \\
\mathrm{Zn}, \mathrm{mg} / \mathrm{kg} \\
\mathrm{Cu}, \mathrm{mg} / \mathrm{kg} \\
\mathrm{Mn}, \mathrm{mg} / \mathrm{kg} \\
\mathrm{Mo}, \mathrm{mg} / \mathrm{kg}\end{array}$ & $\begin{aligned} 53.02 & \pm 0.78 \\
17.05 & \pm 0.07 \\
30.00 & \pm 0.00 \\
20.05 & \pm 0.21 \\
34.00 & \pm 1.98 \\
36.75 & \pm 1.48 \\
4.55 & \pm 0.07 \\
1.63 & \pm 0.00 \\
0.92 & \pm 0.10 \\
0.44 & \pm 0.04 \\
0.35 & \pm 0.04 \\
1.34 & \pm 0.06 \\
0.49 & \pm 0.06 \\
0.26 & \pm 0.04 \\
275.00 & \pm 25.46 \\
69.00 & \pm 1.41 \\
17.50 & \pm 2.12 \\
74.00 & \pm 1.41 \\
0.75 & \pm 0.07\end{aligned}$ \\
\hline
\end{tabular}

${ }^{1}$ Contained $35.2 \% \mathrm{DM} ; 8.3 \% \mathrm{CP}, 22.0 \% \mathrm{ADF}, 39 \% \mathrm{NDF}, 45.8 \% \mathrm{NFC}$, $3.4 \%$ fat, $3.6 \%$ ash, $0.2 \% \mathrm{Ca}, 0.3 \% \mathrm{P}$, and $1.7 \mathrm{Mcal} / \mathrm{kg}$ of $\mathrm{NE}_{\mathrm{L}}(\mathrm{DM}$ basis).

${ }^{2}$ Contained $36.1 \%$ DM; $18.4 \%$ CP, $38.0 \%$ ADF, $52.4 \%$ NDF, $20.5 \%$ NFC, $4.0 \%$ fat, $9.5 \%$ ash, $1.2 \% \mathrm{Ca}, 0.3 \% \mathrm{P}$, and $1.3 \mathrm{Mcal} / \mathrm{kg}$ of $\mathrm{NE}_{\mathrm{L}}$ (DM basis).

${ }^{3}$ Dried bakery by-product.

${ }^{4}$ AminoPlus (Ag Processing Inc., Omaha, NE).

${ }^{5}$ Premix contained $0.296 \%$ of sulfur, $7.183 \mathrm{mg} / \mathrm{kg}$ of selenium, $4.7 \mathrm{mg} /$ $\mathrm{kg}$ of cobalt, $11.76 \mathrm{mg} / \mathrm{kg}$ of iodine, $21.1 \mathrm{mg} / \mathrm{kg}$ of vitamin $\mathrm{A}, 438.56$ $\mu \mathrm{g} / \mathrm{kg}$ of vitamin $\mathrm{D}$, and $685.887 \mathrm{mg} / \mathrm{kg}$ of vitamin E.

${ }^{6} \mathrm{NFC}=100-(\% \mathrm{CP}+\% \mathrm{NDF}+\%$ ash $+\%$ fat $)$.

${ }^{7}$ Estimated based on NRC (2001).

heparinized sterile saline after every blood sample to maintain patency. Blood samples were transferred into evacuated tubes (Becton Dickinson, Rutherford, NJ). Blood tubes containing potassium oxalate and sodium fluoride were used for collecting plasma for analysis of glucose concentration. Blood tubes containing sodium heparin were used for collecting plasma for analyses of BHBA and NEFA concentrations. Blood tubes containing a clot activator (serum separator tubes) were used for collecting serum for analysis of insulin concentration. Blood tubes for plasma collection were immediately placed on ice and centrifuged within $1 \mathrm{~h}$ at 3,300 $\times g$ for 15 min at $4^{\circ} \mathrm{C}$. Blood tubes for serum collection were allowed to remain at room temperature for $1 \mathrm{~h}$ to clot and then centrifuged at $3,300 \times g$ for $15 \mathrm{~min}$ at room temperature. Plasma and serum samples were recovered and frozen at $-20^{\circ} \mathrm{C}$ for further analyses.

\section{Laboratory Analyses}

Samples of the stored forages and TMR were thawed at room temperature, dried for $48 \mathrm{~h}$ at $55^{\circ} \mathrm{C}$ in a forced air oven, and ground in a Wiley mill (A. H. Thomas, Philadelphia, PA) through a 1-mm screen. Samples of the ground forages and TMR were analyzed for DM, CP, soluble $\mathrm{CP}, \mathrm{ADF}, \mathrm{NDF}$, fat, and minerals by wet chemistry (Dairy One Forage Testing Laboratory, Ithaca, NY; Table 1). Dry matter was determined by drying at $135^{\circ} \mathrm{C}$ for $2 \mathrm{~h}$ (method 930.15; AOAC, 2005). Nitrogen was determined by combustion (method 990.03; AOAC, 2005; Leco FP-528 Combustion analyzer, Leco Instruments Inc., St. Joseph, MI) and multiplied by 6.25 to obtain CP. Soluble CP was determined using a sodium borate-sodium phosphate buffer procedure (Roe and Sniffen, 1990). Acid detergent fiber and NDF were determined using the Ankom A200 Filter Bag Technique (Ankom Technology, Macedon, NY) according to Van Soest et al. (1991) with heat-stable amylase and sodium sulfite used in the NDF procedure. Fat was determined using ether extraction (method 2003.05; AOAC, 2005). Minerals were determined using a Thermo Jarrell Ash IRIS Advantage HX Inductively Coupled Plasma Radial Spectrometer (Thermo Instrument Systems Inc., Waltham, MA). Plasma samples were analyzed for glucose (Glucose test procedure no. 1075; Stanbio Laboratory Inc., Boerne, TX) based on the methods of Trinder (1969), BHBA (LiquiColor Test procedure no. 2440; Stanbio Laboratory Inc.) based on the methods of Williamson et al. (1962), and NEFA (Wako NEFA C kit, Biochemical Diagnostics Inc., Edgewood, NY), which was modified according to the procedure of Johnson and Peters (1993). Serum samples were analyzed for concentrations of insulin using an RIA (Coat-A-Count Insulin kit number TKINX, Diagnostic Products Corp., Los Angeles, CA). Inter- and intraassay CV for the insulin RIA was 6.8 and $19.6 \%$, respectively.

\section{Statistical Analysis}

Daily DMI and milk production were averaged to obtain observational means for each period. For serial blood data, areas under the curve were calculated (Matthews et al., 1990) and divided by the sampling time length (720 min) to obtain geometric means to account for unequally spaced measurements. Dependent variables were analyzed by using PROC MIXED (SAS Institute, 
Table 2. Responses of cows fed a lactation TMR supplemented with $250 \mathrm{~g} / \mathrm{d}$ of propylene glycol (PG) as a dry product ${ }^{1}$ incorporated into the TMR or as a top dress (comparison I)

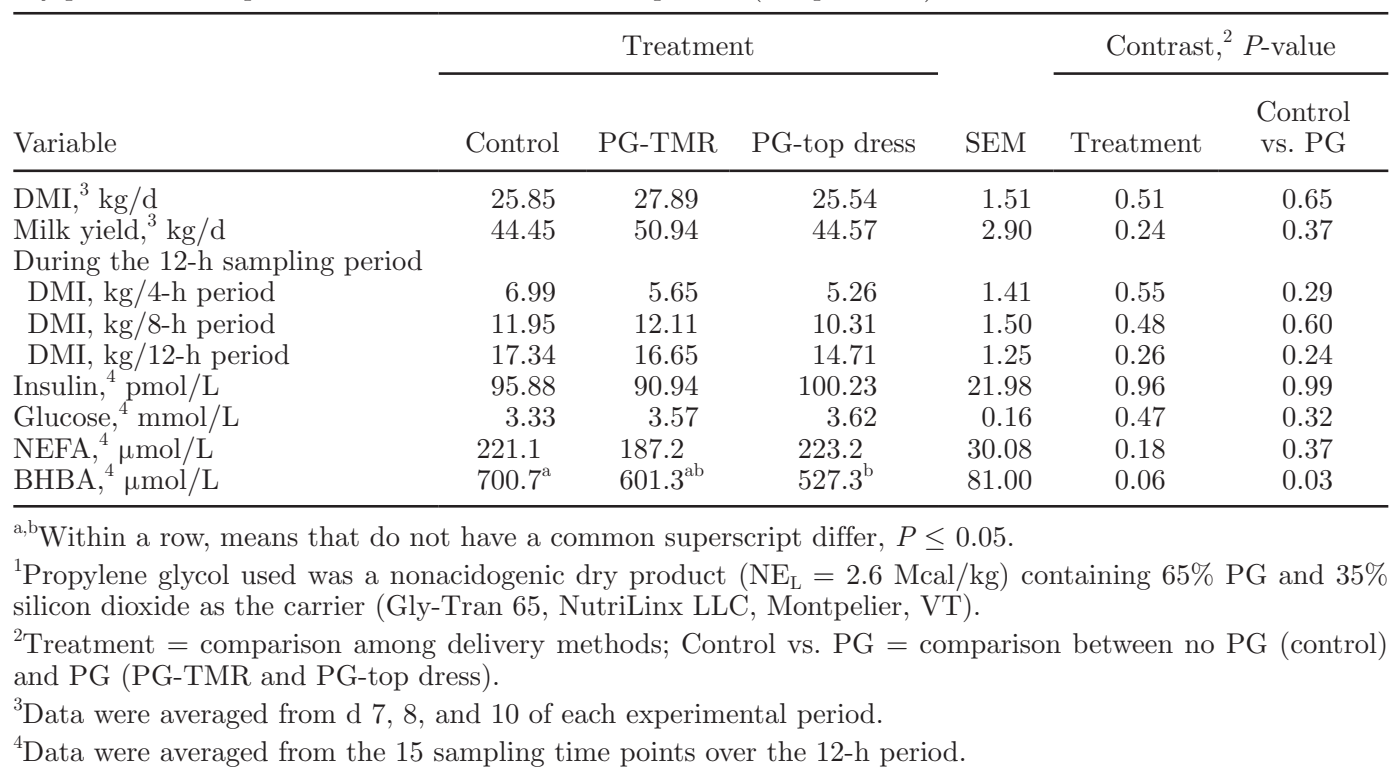

1999). In comparison I, the general linear mixed model included the main effect of delivery method. A contrast for no PG (control) versus PG supplementation (PGTMR and PG-top dress) regardless of method of delivery was preplanned. In comparison II, the general linear mixed model included the main effects of choline, PG, and their interaction. Denominator degrees of freedom were estimated using the Kenward-Roger option in the MODEL statement. Experimental period and cow (or cow nested within treatment) were used in the RANDOM statement. The PDIFF option adjusted by Tukey method was included in the LSMEANS statement to account for multiple comparisons. In comparison III, the general linear mixed model included the linear and quadratic effects of increasing amounts of choline. Time trends for serial blood insulin and metabolite responses were analyzed as repeated measures by using PROC MIXED (SAS Institute, 1999). The sampling time effect and its related interactions with other main effects were added to the general linear mixed model. Sampling time (day or min) was used in the REPEATED statement. Time-series covariance structure was modeled by using the options of autoregressive order one, compound symmetry, unstructured, and spatial power. The best time-series covariance structure was selected based on the lowest Akaike and Bayesian information criteria. Data are presented as means \pm standard deviation or least squares means \pm standard error or standard error of the means. Statistical significance was declared at $P$ $\leq 0.05$, and a tendency to significance was declared at $0.05<P \leq 0.10$.

\section{RESULTS AND DISCUSSION}

\section{Comparison I: Effects of PG Supplementation and Delivery Methods for PG}

The average DMI and milk yield were not affected by PG supplementation and averaged 26.4 and 46.6 $\mathrm{kg} / \mathrm{d}$, respectively (Table 2). No effects of PG supplementation on the average DMI at various time intervals and on the concentrations of serum insulin and blood metabolites, except for BHBA, were observed during the 12-h sampling period after PG administration. The average plasma BHBA concentration during the 12-h sampling period was decreased by PG supplementation from $701 \pm 81$ (control) to $564 \mu \mathrm{mol} / \mathrm{L} \pm 76 \mathrm{SEM}$. Supplementing PG by top-dressing decreased plasma BHBA concentrations more than by incorporating it into the TMR $(527$ vs. $601 \mu \mathrm{mol} / \mathrm{L} \pm 81$ pooled SEM).

Feeding $\mathrm{PG}$ as a dry product via both delivery methods studied in the current study decreased plasma BHBA concentrations over various time intervals, especially for the first $4 \mathrm{~h}$ after administration (Figure 1). The difference on efficacy between the 2 PG delivery methods on plasma BHBA level appeared dependent on the amount of PG that was available to the animal at the time of sampling. For example, PG consumption for the PG-TMR cows was $30 \mathrm{~g}$ on average at $4 \mathrm{~h}$ after administration compared with up to $162.5 \mathrm{~g}$ for the PG-top dressed cows. The better efficacy for PG to reduce plasma BHBA concentration by top dressing was because of the ability of a bolus PG to maintain high 


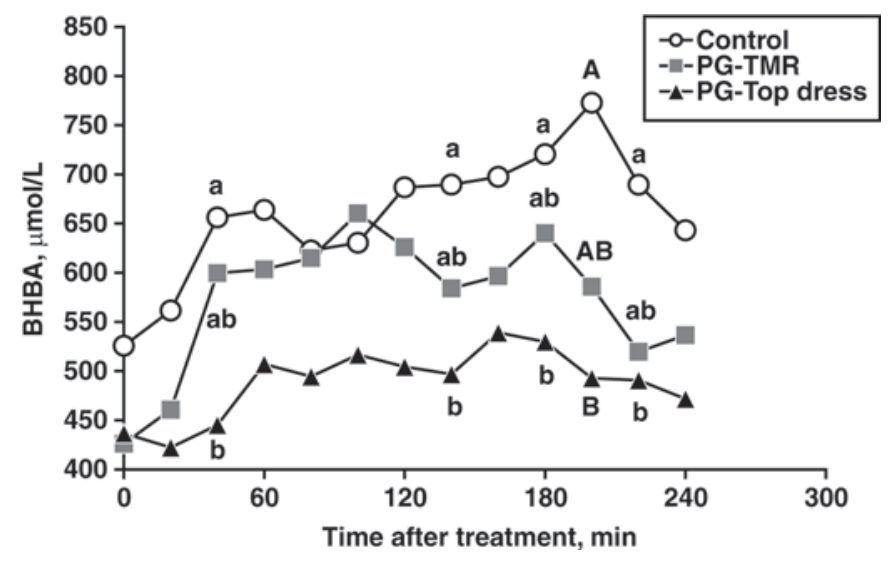

Figure 1. Concentrations of BHBA for cows fed a lactation TMR supplemented with $250 \mathrm{~g} / \mathrm{d}$ of propylene glycol (PG) as a dry product (corresponding to $162.5 \mathrm{~g} / \mathrm{d}$ of PG) incorporated into the TMR (PGTMR) or as a top dress (PG-top dress). Pooled SEM $=104.6$. Method effect: $P=0.32$; time effect: $P<0.01$; method $\times$ time interaction: $P$ $=1.00 .{ }^{\mathrm{A}, \mathrm{B}}$ Difference at $P \leq 0.05 ;{ }^{\mathrm{a}, \mathrm{b}}$ difference at $0.5<P \leq 0.15$. Data for BHBA concentrations at 480 and 720 min after PG administration are not shown (comparison I).

plasma levels for a long period as opposed to a slow-release PG (Kristensen and Raun, 2007). A similar effect of PG as a dry product on plasma BHBA concentration was observed in our previous experiment (Chung et al., 2004) in which the same delivery methods were studied. Kristensen et al. (2002) and Kristensen and Raun (2007) suggested that PG decreases BHBA by 1) decreasing fat mobilization and(or) 2) increasing tissue affinity for BHBA directly via PG itself or indirectly via an endogenous metabolite from the metabolism of PG.

Microbial degradation of $\mathrm{PG}$ produces propionate (Clapperton and Czerkawski, 1972), and an increase in blood propionate concentration stimulates an increase in blood insulin level (Kristensen and Raun, 2007). Insulin is a potent antilipolytic factor that reduces lipolysis in adipose tissue, thereby reducing the release of NEFA from adipocytes to the liver (West and Passey, 1967) and, therefore, subsequent hepatic ketogenesis (Brockman and Laarveld, 1986). Various studies (Grummer et al., 1994; Hoedemaker et al., 2004; Juchem et al., 2004) have shown increases in insulin and subsequent decreases in NEFA and BHBA concentrations by supplementation of PG. In the current study however, responses of plasma NEFA concentration to PG supplementation showed no differences among treatments. These similar plasma NEFA concentrations among treatments could likely be explained by similar insulin concentrations. Other explanations as to why no effects of PG on NEFA were observed in the current study could be the physiological stage of cow and the amount of PG supplemented. Propylene glycol seemed to exert a greater effect on NEFA via insulin during extensive body fat mobilization; for example, the periparturient period (Vázquez-Añón et al., 1994) or feed restriction (Grummer et al., 1994). Cows used in the current study were at $41 \mathrm{DIM} \pm 9 \mathrm{SD}$ at the beginning of the experiment and therefore the degree of body fat mobilization was likely not as excessive as at the beginning of lactation. The amount (corresponding to $162.5 \mathrm{~g} / \mathrm{d}$ ) of PG supplemented in the current study was less than the amounts of PG used in studies in the literature (Nielsen and Ingvartsen, 2004). Sauer et al. (1973) also reported smaller reductions in plasma NEFA and BHBA levels when supplementing PG to cows at 154 versus $308 \mathrm{~g} / \mathrm{d}$. Even with similar insulin and NEFA responses for $12 \mathrm{~h}$ after PG administration as observed in the current study, PG decreased plasma BHBA concentrations, likely indicating an effect of $\mathrm{PG}$ to increase tissue affinity for BHBA without a concurrent effect on insulin.

Higher spikes in serum insulin concentrations during the first $4 \mathrm{~h}$ after PG administration were observed in cows receiving $\mathrm{PG}$ as a top dress compared with those cows receiving no PG or PG as a part of the TMR (Figure 2). Different magnitudes of serum insulin concentration seemed to indicate that the response of insulin to $P G$ was dependent on the amount of PG that was available to the animal at the time of sampling, similar to the response of BHBA to PG. Even with the different magnitudes found for serum insulin concentration, the overall mean insulin concentrations throughout the 12-h sampling period were similar. The percentage increase in insulin from baseline (time 0) to the first and second spikes during the first $4 \mathrm{~h}$ of sampling were 141 and 108, 66 and 19, and 102 and $65 \%$ for cows receiving no PG (control), PG as a part of the TMR (PG-TMR), and $\mathrm{PG}$ as a top dress (PG-top dress), respectively. The higher percentage increase in insulin from the baseline to the first and second spikes observed for the control cows compared with cows receiving other treatments indicated that the amount of feed consumed might have had a greater influence on pancreatic release of insulin. Control cows consumed numerically $(P>0.30)$ more cumulative feed than the PG-supplemented cows with 4.1 versus $3.4,4.7$ versus $4.2,6.2$ versus 5.1 , and 7.0 $( \pm 1.3)$ versus $5.5 \mathrm{~kg}( \pm 1.0$ pooled $\mathrm{SEM})$ at $1,2,3$, and $4 \mathrm{~h}$ after $\mathrm{PG}$ administration, respectively. Bassett (1975) suggested that the magnitude of responses of blood insulin concentration is highly dependent on the amount of food ingested. Therefore, this dietary influence by $1 \times$ feeding/d may have masked the response of insulin to PG supplementation.

Concentrations of insulin were similar among treatments at around $2 \mathrm{~h}$ after feeding. This similarity in insulin concentration at $2 \mathrm{~h}$ after feeding can explain 
similar insulin concentrations observed in our previous experiment (Chung et al., 2004) in which the same delivery methods for PG were evaluated. In that experiment (Chung et al., 2004), blood was sampled once at $2 \mathrm{~h}$ after $\mathrm{PG}$ administration at $4,7,14$, and $21 \mathrm{~d}$ after parturition. A more frequent blood sampling is needed to accurately assess response of insulin concentration in the blood over various time intervals to dietary PG treatment.

\section{Comparison II: Combined Effects of Choline and PG and Comparison III: Dose Response Effects of Choline}

Supplementing choline as RPC, PG as a dry product, or both, did not affect DMI or milk yield (Table 3). The average DMI and concentrations of serum insulin and plasma metabolites during the 12 -h sampling period were not affected by the individual effect of choline or PG or the interaction of choline by PG (Table 3). Plasma BHBA was not reduced by PG likely because of the relatively lower PG intake when fed with the TMR during the sampling period. A significant $(P=0.03)$ 3 -way choline $\times \mathrm{PG} \times$ time interaction was observed for plasma NEFA levels over various time intervals (data not shown). When cows were on the PG+RPC diet they had greater plasma NEFA concentrations at time 0 ; however, this greater plasma NEFA concentration found in cows on the $\mathrm{PG}+\mathrm{RPC}$ diet was not consistent throughout the entire sampling period.

The lack of individual or combined effects of dietary PG and choline supplementation was likely because of cows being in a positive energy status during the course of the experiment and therefore the benefits of dietary

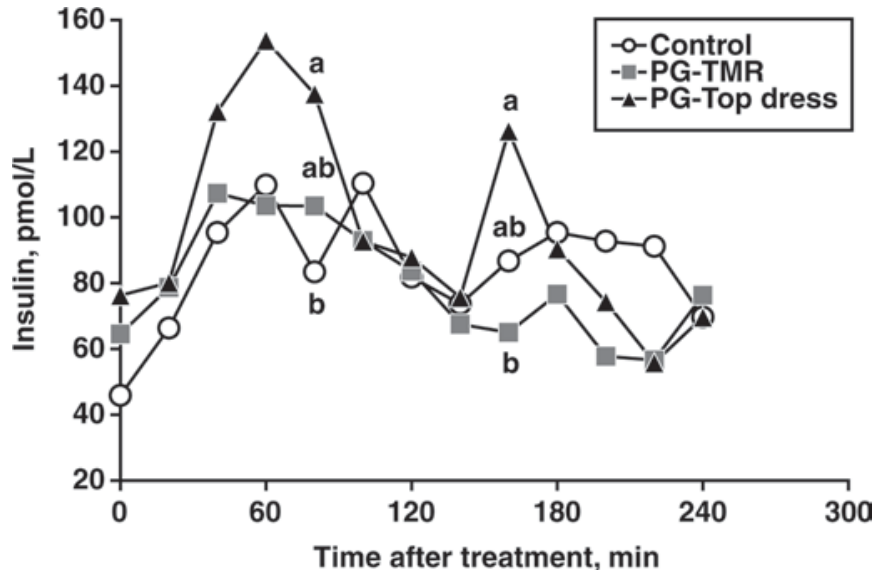

Figure 2. Concentrations of serum insulin for cows fed a lactation TMR supplemented with $250 \mathrm{~g} / \mathrm{d}$ of propylene glycol (PG) as a dry product (corresponding to $162.5 \mathrm{~g} / \mathrm{d}$ of $\mathrm{PG}$ ) incorporated into the TMR (PG-TMR) or as a top dress (PG-top dress). Pooled SEM = 30.5. Method effect: $P=0.78$; time effect: $P<0.01$; method $\times$ time interaction: $P=0.93$. ${ }^{\mathrm{a}, \mathrm{b}}$ Difference at $0.5<P \leq 0.15$. Data for serum insulin concentrations at 480 and 720 min after PG administration are not shown (comparison I).

choline or PG were marginal. Even though energy balance for each cow was not calculated in the current study, the plasma BHBA and NEFA levels observed were below the cutoff value for plasma BHBA $>1,400$ $\mu \mathrm{mol} / \mathrm{L}$ and plasma NEFA $>500 \mu \mathrm{mol} / \mathrm{L}$ that have been proposed to differentiate susceptibility to subclinical ketosis (Duffield et al., 1998; Carrier et al., 2004) and displaced abomasum (LeBlanc et al., 2005), respectively, when cows were in a negative energy balance.

Yield of milk tended to increase linearly $(P=0.08)$ with increasing amounts of RPC, likely because of the numerically greater DMI observed in cows receiving

Table 3. Responses of cows fed a lactation TMR supplemented with propylene glycol (PG) as a dry product, choline as rumen-protected choline (RPC), or both (comparison II)

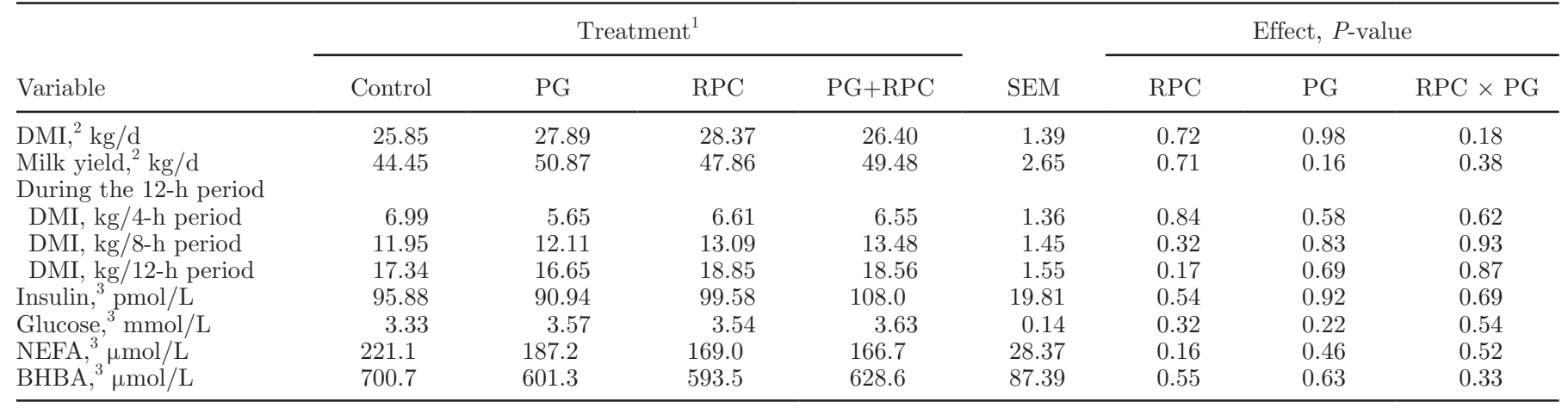

${ }^{1}$ Control = no PG and no choline; PG $=250 \mathrm{~g} / \mathrm{d}$ of PG as a dry product (corresponding to $162.5 \mathrm{~g} / \mathrm{d}$ of PG) incorporated into the TMR; RPC $=50 \mathrm{~g} / \mathrm{d}$ of choline as RPC (estimated to provide $12.5 \mathrm{~g} / \mathrm{d}$ of postruminal choline) top-dressed onto the TMR; PG $+\mathrm{RPC}=$ combination of PG and RPC.

${ }^{2}$ Data were averaged from d 7, 8, and 10 of each experimental period.

${ }^{3}$ Data were averaged from the 15 sampling time points over the 12 -h period. 
Table 4. Responses of cows fed a lactation TMR supplemented with increasing amounts of choline as rumenprotected choline (comparison III)

\begin{tabular}{|c|c|c|c|c|c|c|}
\hline \multirow[b]{2}{*}{ Variable } & \multicolumn{3}{|c|}{ Rumen-protected choline, ${ }^{1} \mathrm{~g} / \mathrm{d}$} & \multirow[b]{2}{*}{ SEM } & \multicolumn{2}{|c|}{$P$-value } \\
\hline & 0 & 25 & 50 & & Linear & Quadratic \\
\hline $\mathrm{DMI},{ }^{2} \mathrm{~kg} / \mathrm{d}$ & 25.98 & 28.22 & 28.48 & 1.95 & 0.30 & 0.60 \\
\hline Milk yield, ${ }^{2} \mathrm{~kg} / \mathrm{d}$ & 44.45 & 48.93 & 47.88 & 3.18 & 0.08 & 0.14 \\
\hline \multicolumn{7}{|l|}{ During the 12 -h period } \\
\hline DMI, kg/4-h period & 6.99 & 6.31 & 6.61 & 1.69 & 0.72 & 0.75 \\
\hline DMI, kg/8-h period & 11.95 & 12.19 & 13.09 & 1.77 & 0.97 & 0.80 \\
\hline DMI, kg/12-h period & 17.34 & 16.98 & 18.85 & 2.05 & 0.63 & 0.46 \\
\hline Insulin, ${ }^{3} \mathrm{pmol} / \mathrm{L}$ & 95.88 & 99.22 & 99.58 & 23.50 & 0.93 & 0.95 \\
\hline Glucose ${ }^{3} \mathrm{mmol} / \mathrm{L}$ & 3.33 & 3.54 & 3.54 & 0.16 & 0.32 & 0.49 \\
\hline $\mathrm{NEFA}^{3}, \mu \mathrm{mol} / \mathrm{L}$ & 221.1 & 194.5 & 169.0 & 28.92 & 0.67 & 0.99 \\
\hline $\mathrm{BHBA},{ }^{3} \mu \mathrm{mol} / \mathrm{L}$ & 700.7 & 689.2 & 593.5 & 74.07 & 0.87 & 0.65 \\
\hline
\end{tabular}

${ }^{1}$ Rumen-protected choline contained $50 \%$ choline chloride and was estimated to be $50 \%$ rumen-protected after in situ incubation in the rumen for $48 \mathrm{~h}$ based on the method by Lykos and Varga (1995).

${ }^{2}$ Data were averaged from $\mathrm{d} 7,8$, and 10 of each experimental period.

${ }^{3}$ Data were averaged from the 15 sampling time points over the 12 -h period.

RPC (Table 4). However, the average DMI and concentrations of serum insulin and plasma metabolites during the 12-h serial sampling period were not affected by increasing RPC. Supplementing choline has been shown to have no effects on DMI for cows during either the prepartum or postpartum period (Piepenbrink and Overton, 2003; Janovick Guretzky et al., 2006), except for overconditioned cows. Zahra et al. (2006) showed that dietary choline supplementation improved DMI in overconditioned (BCS $\geq 4.0$ ) cows during the periparturient period. The ability of dietary choline to improve appetite is perhaps through its ability to improve hepatic function (Piepenbrink and Overton, 2003; Cooke et al., 2007).

\section{CONCLUSIONS}

Feeding PG as a dry product reduced plasma BHBA concentration, but top-dressing PG was more efficient at reducing plasma BHBA level than incorporating $\mathrm{PG}$ into the TMR. Dietary choline as RPC tended to increase milk yield linearly. However, a combined effect of dietary PG and choline was not evident and therefore not beneficial.

\section{ACKNOWLEDGMENTS}

Greatest gratitude is expressed to all personnel at the Pennsylvania State University Dairy Cattle Research and Education Center (University Park) for their constant care for cows. Jugular catheterizations performed by Jacob Werner (Pennsylvania State University), technical and laboratory assistance provided by Samelyse R. Lees (Pennsylvania State University), and rumenprotected choline and dry propylene glycol provided by Paolo Cavassini (Ascor Chimici s.r.l., Via Piana, Italy) and Ivan Girard (Probiotech International Inc., SaintHyacinthe, QC, Canada) are greatly appreciated.

\section{REFERENCES}

AOAC. 2005. Official Methods of Analysis. 18th ed. AOAC Intl., Gaithersburg, MD.

Baldi, A., and L. Pinotti. 2006. Choline metabolism in high-producing dairy cows: Metabolic and nutritional basis. Can. J. Anim. Sci. $86: 207-212$.

Bassett, J. M. 1975. Dietary and gastro-intestinal control of hormones regulating carbohydrate metabolism in ruminants. Pages 383-398 in Digestion and metabolism in the ruminant. I. W. McDonald and A. C. I. Warner, ed., Univ. New England Publ. Unit., Sydney, Australia.

Brockman, R. P., and B. Laarveld. 1986. Hormonal regulation of metabolism in ruminants: A review. Livest. Prod. Sci. 14:313334.

Carrier, J., S. Stewart, S. Godden, J. Fetrow, and P. Rapnicki. 2004. Evaluation and use of three cowside tests for detection of subclinical ketosis in early postpartum cows. J. Dairy Sci. 87:3725-3735.

Chung, Y.-H., K. S. Heyler, T. W. Cassidy, S. L. Ward, I. D. Girard, and G. A. Varga. 2004. Effect of a dry propylene glycol product for postpartum Holstein dairy cows on health and performance. J. Dairy Sci. 87(Suppl. 1):440. (Abstr.)

Clapperton, J. L., and J. W. Czerkawski. 1972. Metabolism of propane-1:2-diol infused into the rumen of sheep. Br. J. Nutr. $27: 553-560$.

Cooke, R. F., N. S. Del Rio, D. Z. Caraviello, S. J. Bertics, M. H. Ramos, and R. R. Grummer. 2007. Supplemental choline for prevention and alleviation of fatty liver in dairy cattle. J. Dairy Sci. 90:2413-2418.

Duffield, T. F., D. Sandals, K. E. Leslie, K. Lissemore, B. W. McBride, J. H. Lumsden, P. Dick, and R. Bagg. 1998. Efficacy of monensin for the prevention of subclinical ketosis in lactating dairy cows. J. Dairy Sci. 81:2866-2873.

Fisher, L. J., J. D. Erfle, and F. D. Sauer. 1971. Preliminary evaluation of the addition of glucogenic materials to the rations of lactating cows. Can. J. Anim. Sci. 51:721-727.

Grummer, R. R., J. C. Winkler, S. J. Bertics, and V. A. Studer. 1994. Effect of propylene glycol dosage during feed restriction on metabolites in blood of prepartum Holstein heifers. J. Dairy Sci. $77: 3618-3623$

Hoedemaker, M., D. Prange, H. Zerbe, J. Frank, A. Daxenberger, and H. H. D. Meyer. 2004. Peripartal propylene glycol supplementation 
and metabolism, animal health, fertility, and production in dairy cows. J. Dairy Sci. 87:2136-2145.

Janovick Guretzky, N. A., D. B. Carlson, J. E. Garrett, and J. K. Drackley. 2006. Lipid metabolite profiles and milk production for Holstein and Jersey cows fed rumen-protected choline during the periparturient period. J. Dairy Sci. 89:188-200.

Johnson, M. M., and J. P. Peters. 1993. Technical note: An improved method to quantify nonesterified fatty acids in bovine plasma. J. Anim. Sci. 71:753-756.

Johnson, R. B. 1954. The treatment of ketosis with glycerol and propylene glycol. Cornell Vet. 44:6-21.

Juchem, S. O., F. A. Santos, H. Imaizumi, A. V. Pires, and E. C. Barnabe. 2004. Production and blood parameters of Holstein cows treated prepartum with sodium monensin or propylene glycol. J. Dairy Sci. 87:680-689.

Kristensen, N. B., A. Danfaer, B. A. Rojen, B. M. Raun, M. R. Weisbjerg, and T. Hvelplund. 2002. Metabolism of propionate and 1,2-propanediol absorbed from the washed reticulorumen of lactating cows. J. Anim. Sci. 80:2168-2175.

Kristensen, N. B., and B. M. Raun. 2007. Ruminal and intermediary metabolism of propylene glycol in lactating Holstein cows. J. Dairy Sci. 90:4707-4717.

LeBlanc, S. J., K. E. Leslie, and T. F. Duffield. 2005. Metabolic predictors of displaced abomasum in dairy cattle. J. Dairy Sci. $88: 159-170$.

Lewis, E. F., and E. K. Price. 1957. The use of choline chloride as a lipotropic agent in the treatment of bovine liver dysfunction. Br. Vet. J. 113:242-246.

Lykos, T., and G. A. Varga. 1995. Effects of processing method on degradation characteristics of protein and carbohydrate sources in situ. J. Dairy Sci. 78:1789-1801.

Matthews, J. N. S., D. G. Altman, M. J. Campbell, and P. Royston. 1990. Analysis of serial measurements in medical research. BMJ 300:230-235.

Nielsen, N. I., and K. L. Ingvartsen. 2004. Propylene glycol for dairy cows: A review of the metabolism of propylene glycol and its effects on physiological parameters, feed intake, milk production and risk of ketosis. Anim. Feed Sci. Technol. 115:191-213.
NRC. 2001. Nutrient Requirements of Dairy Cattle. 7th rev. ed. Natl. Acad. Sci., Washington, DC.

Patton, R. S., C. E. Sorenson, and A. R. Hippen. 2004. Effects of dietary glucogenic precursors and fat on feed intake and carbohydrate status of transition dairy cows. J. Dairy Sci. 87:2122-2129.

Piepenbrink, M. S., and T. R. Overton. 2003. Liver metabolism and production of cows fed increasing amounts of rumen-protected choline during the periparturient period. J. Dairy Sci. 86:17221733.

Roe, M. B., and C. J. Sniffen. 1990. Techniques for measuring protein fractions in feedstuffs. Pages 81-88 in Proc. Cornell Nutr. Conf. Feed Manuf., Cornell Univ., Ithaca, NY.

SAS Institute. 1999. SAS/STAT User's Guide: Statistics. Version 8 ed. SAS Inst. Inc., Cary, NC.

Sauer, F. D., J. D. Erfle, and L. J. Fisher. 1973. Propylene glycol and glycerol as a feed additive for lactating dairy cows: An evaluation of blood metabolite parameters. Can. J. Anim. Sci. 53:265-271.

Trinder, P. 1969. Determination of glucose in blood using glucose oxidase with an alternative oxygen acceptor. Ann. Clin. Biochem. 6:24-27.

Van Soest, P. J., J. B. Robertson, and B. A. Lewis. 1991. Methods for dietary fiber, neutral detergent fiber, and nonstarch polysaccharides in relation to animal nutrition. J. Dairy Sci. 74:3583-3597.

Vázquez-Añón, M., S. Bertics, M. Luck, R. R. Grummer, and J. Pinheiro. 1994. Peripartum liver triglyceride and plasma metabolites in dairy cows. J. Dairy Sci. 77:1521-1528.

West, C. E., and R. F. Passey. 1967. Effect of glucose load and of insulin on the metabolism of glucose and of palmitate in sheep. Biochem. J. 102:58-64.

Williamson, D. H., J. Mellanby, and H. A. Krebs. 1962. Enzymic determination of $\mathrm{D}(-)$-beta-hydroxybutyric acid and acetoacetic acid in blood. Biochem. J. 82:90-96.

Zahra, L. C., T. F. Duffield, K. E. Leslie, T. R. Overton, D. Putnam, and S. J. LeBlanc. 2006. Effects of rumen-protected choline and monensin on milk production and metabolism of periparturient dairy cows. J. Dairy Sci. 89:4808-4818. 